\title{
FRAGILE, ROBUST AND ANTIFRAGILE SERVICES
}

\section{MAREK DUTKOWSKI}

University of Szczecin, Faculty of Geosciences, POLAND

e-mail: marek.dutkowski@usz.edu.pl

RECEIVED
ACCEPTED
JEL
CLASSIFICATION

KEYWORDS

ABSTRACT
10 December 2018

28 December 2018

D81, H12, L80

Taleb's concept; fragile, robust and antifragile services

The contemporary economy, including the service sector, is exposed to strong, violent and unexpected impacts (shocks, crises, challenges, opportunities) of an internal and external nature. The purpose of the paper presented here is to attempt to characterize and classify service activities in the light of Taleb's concept, who divided all existing real things into three categories: fragile, robust, and antifragile. Each of these types of things react differently to changes, especially those least expected and leading to fundamental changes, called by Taleb "black swans". The conditions of such changes in relation to the service activities were given. Also were determined general features of consumer, business, and public services according to fragility, robustness and antifragility, as well as some examples of them. The statements contained in the article are hypotheses, but according to the author, sufficiently justified by the current state of knowledge.

\section{Introduction}

Service activities form the backbone of the modern world economy, and the majority of employees work in them. In highly developed countries, they form the dominant part of GDP, in less developed they create numerous jobs with higher efficiency than agriculture, fisheries or mining. They also help to improve the quality of life. These activities, strongly diversified, were adopted to be called the tertiary sector, according to the Fisher-Clark concept 
(see e.g. Kwiatkowski, 1980; Zajdel, 2011; Skórska, 2016). Despite intensive research conducted within various disciplines, knowledge about the functioning and development of services is still incomplete and imperfect. One of the reasons is the emergence of new service activities, related to technical progress and changing needs of consumers, public organizations, and enterprises.

The contemporary economy, including the service sector, is exposed to strong, violent and unexpected impacts (shocks, crisis, challenges, but also opportunities, chances) of an internal and external nature. In the studies of these interactions, and in practice, in order to minimize of their negative effects, we need different approaches from those commonly used. One of such approaches is the concept of describing and explaining the reactions of complex systems to threats and opportunities in terms of their fragility, robustness, and antifragility, developed by Nassim Nicholas Taleb (2013). These concepts have come to general scientific knowledge and are defined as follows:

Fragility. Susceptibility of an item to breakage, failure, or loss of value from the impact of external forces, measured as the amount of force required to cause the damage. ${ }^{1}$

Robustness. Characteristic of product, process, or system designed for continuous operation with very low downtime, failure rate, variability, and very high insensitivity to a continually changing external environment. ${ }^{2}$

Antifragility is a property of systems that increase in capability as a result of stressors, shocks, volatility, noise, mistakes, faults, attacks, or failures. According to N.N. Taleb (2013) "Antifragility is beyond resilience or robustness. The resilient resists shocks and stays the same; the antifragile gets better". ${ }^{3}$

In this article, presented above way of thinking about complex objects will be called the "Taleb's concept". This approach was already used by the author in the research of the maritime economy and coastal cities in Poland (Dutkowski, 2017). The purpose of the considerations presented here is to attempt to characterize service activities in the light of Taleb's concept. The statements contained below are hypothetical, but these are hypotheses, according to the author, sufficiently justified by the current state of knowledge.

\section{The Taleh's concept}

Nassim Nicholas Taleb (2013) divided all existing real things, systems and units into three categories: resistant, fragile and antifragile. This author refers to another own concept of the so-called "black swans", i.e. unpredictable events, initially seemingly insignificant, but causing, after some time, severe disturbances and leading to profound and irreversible changes (Taleb, 2014). The appearance of the "black swan" in the life of some complex thing (ecosystem, person, family, social group, nation, state, economic sector, institution, enterprise, region or city) means that nothing is the same anymore and everything is happening differently. Such events may be positive or negative. Negative "black swans", or "catastrophes" and "unlucky events" can have three different consequences: fragile things undergo devastation and decay, robust ones are able to withstand the shock and without fundamentally changing their structure and operating principles, return to the smooth functioning and development whereas the antifragile things are obviously disturbed, even very severely, but ultimately they emerge from the crisis stronger, better, and more developed. Positive "black swans", or occasions and "won in the lottery" are not used by robust

\footnotetext{
${ }^{1}$ www.businessdictionary.com/definition/robust.html.

${ }^{2}$ www.businessdictionary.com/ definition/fragility.html.

${ }^{3}$ https://en.wikipedia.org/wiki/Antifragility.
} 
things, because they often do not see them, disrespect them or are very reluctant to any changes, fragile things are so overwhelmed by the new situation that they are not able to use all the possibilities resulting from them, and the best are the emergence of positive "black swans" antifragile things, which by nature are ready for change, await their great opportunity and constantly hope that they will succeed.

Complex things are not condemned to one type of reaction to crises. It also depends on the type of crisis. In some cases, fragile things can show immunity, and resistant to react like anti-friction. Again an analogy to the health condition of a human being - the resistance to viruses and bacteria can be combined with psychological fragility in difficult situations, and people of poor health may show significant resistance to stress. In general, however, very complex and complex things show a certain integrity, resulting from their structure and the most common ways of acting, and belonging to one of the types from the Taleb's concept is their essential property determining the response to crises.

\section{Sources of erises in the services sector}

The sources of sudden and significant challenges for enterprises and their groupings in the services sector may be internal or external. Internal sources are a faulty market strategy, inefficient management and personnel problems. Each of them, and especially together, may be the cause of a serious, most often unexpected crisis. Prevention and counteracting such adverse events is the subject of a separate field of crisis management knowledge and activities (e.g. Baubion, 2013). These types of internal threats concern, in fact, all enterprises, public institutions and social organizations, regardless of the economic sector or the sphere of social activity.

External sources, which are more important, can be divided into natural, social, technological and market ones. Natural disasters are most often unexpected, especially when it comes to them in the same place and time. These types of crises are caused by earthquakes, volcanic eruptions, hurricanes, floods, waves of heat, droughts, expansion of alien species of animals and plants, but also epidemics among people and among animals. This is despite technologically advanced monitoring and warning systems against natural disasters and epidemics.

Natural disasters destroy and damage primarily buildings and technical infrastructure. They also lead to financial losses and cause long-lasting psychological and social effects. Of course, they require extraordinary activities of public administration, police, emergency and medical services, and sometimes even army. Service activities, whose operation depends to a large extent on buildings, equipment and technical infrastructure, may react differently, showing fragility, robustness or antifragility. Numerous empirical studies show that local communities, as well as public and private providers of basic services related to people's existence, saving lives and health, securing damages and rebuilding from destruction, show antifragility in such situations.

The strongest social sources of crises in the services sector are international and domestic armed conflicts. Similar negative effects bring revolutions. Also violent, non-military conflicts leading to strikes and street riots. The change in the political system (such as the transformation of the Soviet bloc countries since 1990), resulting in a thorough change in the legal conditions of the functioning of the economy, is the source of numerous challenges for the services sector. As experience indicates, some use them as an opportunity and achieve revenues that are incomparable to the times of peace (e.g. trade of weapons, medicines, sometimes food). However, public services suffer huge losses, even for armed forces and police. 
Economic sources of crises in the services sector are the result of social crises, but often they are the result of rapid changes in economic relations: currency and foreign trade, banking, budget, but also changes in customer preferences and resulting changes in demand. Such crises also create both opportunities and threats.

Technological sources of crises in the services sector result from the emergence or disappearance of technological solutions used by service providers or customers. The emergence of the Internet, smartphones, artificial intelligence, medical therapies and the possibility of modifying the human body has led to the disappearance of certain types of services (e.g. postal services) and the emergence of new ones (e.g. internet commerce).

\section{General features of fragile, robust, and antifiragile services}

Using the Taleb's concept, one can indicate the features of service activities, which can be attributed to the property of fragility, robustness and antifragility. Such typical features, based on a table published by N.N. Taleb (2013, pp. 48-52) are presented in the Table 1. As already mentioned above, the features of three types of services presented in this table - fragile, robust and antifragile, which also concern other sectors of the economy, have the character of a theoretical and methodological proposal. Only empirical studies of individual companies, their groupings and industries will allow them to assess them. At this stage of application of the Taleb's concept in scientific research they seems to be justified and legitimate.

Table 1. General features of services activities in the light of Taleb's concept

\begin{tabular}{lccc}
\hline \multicolumn{1}{c}{ Features of service activities } & & Service activities & \\
\cline { 2 - 4 } & fragile & robust & antifragile \\
\hline Company size & big & medium to big & small to medium \\
Owner & corporate/public & public/private & private/personal \\
Amount of customers & large & large to medium & small to large \\
Diversity of customers & low & average & high \\
Amount of products & low & average & small to large \\
Diversity of products & low & average & high \\
Specialization & not specialized & specialized & not specialized \\
Profitability level & high & average & low to high \\
Diversification of profitability & low & low & high \\
Dependence on technology, equipment, and facilities & high & average & low to high \\
Qualifications of the staff & high & average & low to high \\
Ability to learn & low & medium & high \\
Epistemology & truth/false & useful/not useful & gull/not a gull \\
Propensity to risk & low & medium & high \\
Finansing & debt (public) & public/equity capital & venture capital \\
Black Swans & exposure to negative & indifference towards & Black Swans \\
\hline
\end{tabular}

Source: own study based on Taleb (2013), pp. 48-52.

Classification of services according to the criteria of fragility, robustness, and antifragility.

The notion of "service activities" could be defined in different ways, depending on the purpose of the research or applications. However, there is a general agreement that services are economic activities aimed at satisfying collective and individual needs without transfer of material goods. They can be classified by to the criterion of their 
character, impact range, frequency of use, hierarchy, location and sources of financing. The most important classifications of service activities are: the United Nations' International Standard Industrial Classification (ISIC), the Statistical Classification of Economic Activities in the European Community (NACE), and national systems, e.g. in Poland - Polska Klasyfikacja Wyrobów i Usług (PKWiU).

Taleb's concept introduces different criteria for the classification of service activities. Due to the diversity of the frequency of fragile, robust and antifragile services, it is justified, however, to adopt a simple and commonly accepted division of service activities according to the criteria of their recipient on: consumer, business, and public services.

According to these three groups, examples of service activities are classified on the basis of the features presented in Table 1 to be described as fragile, robust or antifragile. The intended scope of this article does not allow for a wider justification of such an assignment, it should be treated as hypothetical, but justified by available knowledge and knowledge of individual cases. The various types of service activities classified according to the Taleb's concept and presented in Table 2 were discussed only in a general way.

Tahle 2. Classification of service activities in the light of Taleb's concept

\begin{tabular}{|c|c|c|c|}
\hline \multirow{2}{*}{$\begin{array}{l}\text { Types of service activities due } \\
\text { to the type of their clients }\end{array}$} & \multicolumn{3}{|c|}{ Types of service activities due to their reactions to sudden crises } \\
\hline & fragile & robust & antifragile \\
\hline Consumer services & $\begin{array}{l}\text { - Hospitality services } \\
\text { - Legal and financial services for } \\
\text { private individuals } \\
\text { - Movie theatres } \\
\text { - Private medical and care services } \\
\text { - Radio, television and printed press } \\
\text { - Theatres, philharmonics, operas } \\
\text { - Sport, tourism and leisure services }\end{array}$ & $\begin{array}{l}\text { - Death care } \\
\text { - Gambling } \\
\text { - Private maternity services } \\
\text { - Sexual and porn services }\end{array}$ & $\begin{array}{l}\text { - Construction, repair, } \\
\text { maintenance and household } \\
\text { management } \\
\text { - Direct delivery of individual } \\
\text { customer goods } \\
\text { - Gastronomy } \\
\text { - Individual transport services } \\
\text { - Information services } \\
\text { - Performing arts productions } \\
\text { - Beauty services } \\
\text { - Retail trade }\end{array}$ \\
\hline Business services & $\begin{array}{l}\text { - Financial services } \\
\text { - Risk management }\end{array}$ & $\begin{array}{l}\text { - Logistics } \\
\text { - Technical infrastructure } \\
\text { management }\end{array}$ & $\begin{array}{l}\text { - Business functions (general) } \\
\text { - Information services }\end{array}$ \\
\hline Public services & $\begin{array}{l}\text { - Armed forces } \\
\text { - Internal and external security } \\
\text { agencies } \\
\text { - Police } \\
\text { - Public administration } \\
\text { - Public utilities connected with } \\
\text { facilities and technical infrastructure }\end{array}$ & $\begin{array}{l}\text { - Education } \\
\text { - Public death care } \\
\text { - Public maternity services } \\
\text { - Public medical and care } \\
\text { services } \\
\text { - Public rescue services } \\
\text { - Religious services }\end{array}$ & $\begin{array}{l}\text { - Spontaneous public rescue, } \\
\text { medical, and security services }\end{array}$ \\
\hline
\end{tabular}

Attention: Types of services in individual columns have been sorted alphabetically.

Source: own study.

Fragile service activities include both numerous consumer and public services. Most of them are large, hierarchical enterprises or their groupings and state institutions, related to internal or external security, media supply, road and rail infrastructure, but also sport, tourism and recreation, but also sexual and porn services. They are sensitive to various types of crises, discussed above. The most dangerous for the entire economy and society is the fragility of financial services for business and individual clients, especially large banks and insurance companies, as evidenced by the events of 2008/2009. Budgetary difficulties also lead to deterioration in the 
activities of many public services. Long-term political conflicts, especially the break-up and collapse of states, result in the disintegration of the state administration, the police and the armed forces. Of course, the lost war leads to similar effects. Examples of this type of events, however, vary in their range, include Iraq, Somalia, Greece and, more recently, Venezuela.

Robust service activities include not very diverse types of service activities. They are related to the basic needs of people associated with birth, health, education, religious faith, care for children and the elderly and the disabled, saving lives and property and death, but also the needs related to gambling, prostitution and pornography. Robustness exhibits logistics and technical infrastructure management among business services. Of course, various types of crises may lead to a deterioration of the quality or limitation of the offer, but historical experience indicates that even gambling and prostitution are permanent elements of numerous, though not all, civilizations. People are born, get sick, grow old and die, which causes demand for certain services. Both in exclusive neighborhoods and in the slums. Both in Kuwait and South Sudan.

The most interesting in the context of the Taleb's concept are the antifragile service activities. These include, above all, services related to satisfying the above-basic needs of people, are subject to rapid technological and cultural changes and influences of fashion, media and trendsetters: home maintenance and repairs, cleaning, repair of cars and other equipment, delivery services to home, transport of people, provision of information (currently implemented mainly via the Internet), beauty services (including plastic surgery). Among the antifragile business services are accounting, secretarial and information services. An important type of antifragile services is any artistic activity, from composing operas and writing novels to street dance and graffiti makers. The success in all these activities results not only from talent and diligence, but often also from happy coincidences and the whims of consumers of artistic activity. The most diverse antifragile services, however, are located in retail and catering from the offering of a few bananas or a bowl of cooked rice traders in the slums of African cities to luxury department stores and boutiques as well as restaurants and cafes of New York, Paris, London or Tokyo and the Wal-Mart or Amazon network as well.

\section{Conclusions}

The Taleb's concept is an interesting starting point for a different view of the services sector from the previous view. If you accept the division of service activities as useful, it opens up a new research perspective of managing services and providing services fragile and robust to antifragile.

\section{References}

Baubion, Ch. (2013). Risk Management: Strategic Crisis Management Charles. Paris: OECD.

Dutkowski, M. (2017). Miasta nadmorskie wobec kryzysów gospodarki morskiej - odporne, kruche czy antykruche? In: R. Anisiewicz, M. Połom, M. Tarkowski (eds.), Rozwój regionalny i lokalny w perspektywie geograficznej (pp. 23-48). Gdańsk: Uniwersytet Gdański, Katedra Geografii Rozwoju Regionalnego.

https://en.wikipedia.org/wiki/Antifragility.

Kwiatkowski, E. (1980). Teoria trzech sektorów gospodarki: prezentacja i próba oceny. Warszawa: PWN.

Skórska, A. (2016). Determinanty i perspektywy rozwoju sektora usług w Polsce - zmiany wewnątrzsektorowe. Prace Komisji Geografii Przemysłu Polskiego Towarzystwa Geograficznego, 30 (4), 7-20.

Taleb, N.N. (2013). Antykruchość. O rzeczach, którym służą wstrząsy. Warszawa: Kurhaus. 
Taleb, N.N. (2014). Czarny łabędź. O skutkach nieprzewidywalnych zdarzeń. Warszawa: Kurhaus.

www.businessdictionary.com/definition/robust.html.

www.businessdictionary.com/ definition/fragility.html.

Zajdel, M. (2011). Trójsektorowa struktura gospodarcza w Polsce jako miernik rozwoju (wybrane aspekty). Nierówności Społeczne a Wzrost Gospodarczy, 18, 419-430.

Cite this article aS: Dutkowski, M. (2018). Fragile, Robust and Antifragile Services. European Journal of Service Management, 4 (28/2), 149-155. DOI: 10.18276/ejsm.2018.28/2-18. 